\title{
Evaluation Trial on Bottle Gourd [Lagenaria siceraria] Under Prayagraj Agro-Climatic Conditions
}

\author{
Nikkula Chandra Leela* and Devi Singh
}

Department of Horticulture, Naini Agricultral Institute SAM Higginbottom University of Agriculture, Technology and Sciences, Prayagraj, Uttar Pradesh, India

*Corresponding author: chandraleelanikkula@gmail.com (ORCID ID: 0000-0002-0656-1429)

Paper No. 875

Received: $16-07-2020$

Revised: $27-10-2020$

Accepted: $30-11-2020$

\begin{abstract}
The present investigation entitled "Evaluation trail on bottle gourd (Lagenaria siceraria) under Prayagraj Agro-climatic conditions was conducted at Horticulture Research farm at Department of Horticulture, SHUATS, Naini, Prayagraj from July to Oct 2019. The experimental soil was sandy loam in texture with a $\mathrm{pH}$ of 7.0 to $8.0,0.480$ organic carbon, and $280,12.3$, and $150 \mathrm{~kg} / \mathrm{ha}^{-1}$ of available $\mathrm{N}$, P, and K, respectively. The main objective of the experiment is to find out the most suitable variety of bottle gourd for better growth under Prayagraj, Agro-climatic conditions. Twenty six bottle gourd varieties were evaluated for different quantitative characters using Randomized Block Design (RBD) with the aim to identify the most suitable variety. Among twenty six varieties, the variety 2016/BOGVAR-1exhibited days to first harvest (49.55DAT).

Highlights

( Twenty six bottle gourd varieties were evaluated for different quantitative characters using Randomized Block Design (RBD) with the aim to identify the most suitable variety.
\end{abstract}

Keywords: Bottle gourd, varieties and yield

Bottle gourd [Lagenaria siceraria (Molina) Standl. $2 n=22]$ is an important cucurbitaceous crop grown throughout the country. It is a warm-season vegetable, which thrives well in a warm and humid climate, but it can be grown throughout the year in Nor then India plains as an off-season vegetable. The young and tender fruits of bottle gourd are mostly used as a vegetable. However, delicious preparations like burfee, rayata, halwa, pathe etc. are also common.

Dry shells of the mature fruits are used to make containers and musical instruments. Different parts of bottle gourd have got medicinal properties also. It contains $96.3 \%$ water, $2.9 \%$ carbohydrates, $0.2 \%$ protein, $0.5 \%$ fat, $0.5 \%$ mineral matter, $11 \mathrm{mg}$ of vitamin C per $100 \mathrm{~g}$. Bottle gourd is a monoecious crop with an exceptional and andromonoecious sex form (Singh et al. 1996). It is a highly cross- pollinated crop in which a large amount of variation is observed in many economically important traits. The crop is well suited for improvement through inbreeding followed by selection without significant loss in vigor. Therefore, high-yielding inbreeds can be developed with a desirable level of uniformity in agronomically important morphological traits.

India is considered the secondary centre of diversity for bottle gourd. It exhibits a great range of variability with respect to its morphological traits, maturity period, and fruit yield potential. The genotypes also differ with respect to adaptability to summer and cool seasons (Rakshit et al. 2020). Eastern Uttar Pradesh is one of the rich zones

How to cite this article: Leela, N.C. and Singh, D. 2020. Evaluation Trial on Bottle Gourd [Lagenaria siceraria] Under Prayagraj Agro-Climatic Conditions. IJAEB, 13(4): 517-520.

Source of Support: None; Conflict of Interest: None 
exhibiting the diversity of bottle gourd. Since this area remains frost-free, bottle gourd cultivation round the year is a common practice, although, during winter, it is mainly grown on thatches, huts, and roof-tops. Thus this region also exhibits genetic diversity with respect to cool-season adaptability.

During the last two decades, there has been constant progress in the development of improving varieties of bottle gourd by the public as well as private sectors, particularly in the number of hybrid varieties. However, the cultivation of bottle gourd mainly depends on local varieties and landraces in eastern Uttar Pradesh, Uttar Pradesh is mainly known for its Rice and Wheat growing areas. The agro-climatic condition of the state is also suitable for the cultivation of all kinds of vegetables. Among them, bottle gourd is also one of the important vegetables. There is a vast scope for cultivation of bottle gourd in Uttar Pradesh as there is a regular demand of crop for a vegetable as well as for medicinal uses. It is a highly remunerative crop which fetches sizeable income to the farmer within two or three months.

Uttar Pradesh is known for its biodiversity, particularly Prayagraj as it comes under Agroclimatic zone $-\mathrm{V}$, which is the upper Gangetic plains region. In bottle gourd, maximum diversity is found for its fruit shape, fruit color, size, seed color, vine length, and duration.

Collection and evaluation of genotypes is a prerequisite for their utilization, and detailed evaluation determines the potential of accession in a specific crop improvement program. Nowadays, farmers are demanding early maturing and high yielding varieties of bottle gourd. To meet out the needs of farmers, preliminary work should be initiated from the identification of high yielding genotypes, which can be utilized as a variety or further varietal development program. Therefore, a trial for evaluation of presently available bottle gourd genotypes was carried out entitled "Evaluation trial on bottle gourd [Lagenaria siceraria] under prayagraj agro-climatic conditions".

Keeping the above facts in view the present investigation, using the available varieties released from the different private sectors and local varieties. The investigation was taken up with the following -To find out the most suitable variety of bottle gourd for better growth and yield.

\section{MATERIALS AND METHODS}

Department of Horticulture, Naini Agricultural Institute, SHUATS, Prayagraj, falls under the humid subtropical zone. Maximum rainfall was received during the period between July to the end of September. However, occasional showers are also very common in the month of June, December, and January. The winter month will usually cool and dry. The summer is hot, and dry western hot winds start from April and end at the onset of monsoon.

The study was conducted in the Research Field, Department of Horticulture, Naini Agriculture Institute, SHUATS, Prayagraj, located between $25.87^{\circ}$ North latitude $81.15^{\circ}$ East latitude. The altitude is 78 meters above the mean sea level during the season of 2019. The soil was sandy loam in texture having moderate water holding capacity with a $\mathrm{pH}$ of 7.0 to $8.0,0.480$ organic carbon and 280, $12.3,150 \mathrm{~kg} / \mathrm{ha}$ ' N, P, and K, respectively. Twenty-six bottle gourd varieties were evaluated for different quantitative characters using Randomized Block Design (RBD).

From the results, it is clearly observed that the seeds are sown in pits after the 8 days of land preparation in the $2^{\text {nd }}$ week of July 2019 at a depth of 2.5 to $3 \mathrm{~cm}$. The crop received a total rainfall of $1012.3 \mathrm{~cm}$ during the period of experimentation. Observations on growth parameters of Bottle gourd were recorded and analyzed statistically.

\section{RESULTS AND DISCUSSION}

Analysis of variance showed significant differences among the varieties for the different characters studied at $0.1 \%$ and $5 \%$ significance. The analysis of variance revealed a highly significant difference in the number of tillers $/ \mathrm{m}^{2}$ among treatments. Days to germination varied from 7.67 to 12.66 days. Maximum days of 12.66 required for germination was recorded in case of variety 2018/BOGHYB-5, Minimum days of 7.67 was recorded in case of 2018/BOGHYB-2 Maximum vine length was recorded in BOGVAR-3 (6.47) variety followed by variety BOGVAR-3 (6.33) at 90 DAS. The lowest vine length was recorded in SHIVA-60 $(4.55 \mathrm{~m})$. Internodal length varied from 8.96 to $13.77 \mathrm{~m}$. Minimum internodal length $8.96 \mathrm{~cm}$ was recorded in case of variety 2018/BOGVAR-1, and Maximum internodal length was recorded in BOGVAR-4 
Table 1: List of varieties used in the present investigation and the growth of Bottle gourd (Lagenaria siceraria) under Prayagraj agro-climatic conditions

\begin{tabular}{|c|c|c|c|c|c|c|c|c|c|c|}
\hline Notation & Variety & $\begin{array}{l}\text { Days to } \\
\text { germination }\end{array}$ & $\begin{array}{l}\text { Vine } \\
\text { length } \\
\text { (m) }\end{array}$ & $\begin{array}{l}\text { Internodal } \\
\text { length } \\
(\mathrm{cm})\end{array}$ & $\begin{array}{l}\text { No. of } \\
\text { primary } \\
\text { branches }\end{array}$ & $\begin{array}{l}\text { Petiole } \\
\text { length } \\
\text { (cm) }\end{array}$ & $\begin{array}{l}\text { Leaf } \\
\text { length } \\
\text { (cm) }\end{array}$ & $\begin{array}{l}\text { Leaf } \\
\text { width } \\
\text { (cm) }\end{array}$ & $\begin{array}{l}\text { Days to } \\
1^{\text {st }} \text { female } \\
\text { flower } \\
\text { appearance }\end{array}$ & $\begin{array}{l}\text { Days } \\
\text { to } 1^{\text {st }} \\
\text { harvest }\end{array}$ \\
\hline$\overline{\mathrm{V}}$ & 2018/BOGHYB-1 & 8.50 & 5.85 & 9.80 & 4.05 & 15.13 & 15.75 & 8.53 & 39.76 & 50.50 \\
\hline V2 & 2018/BOGHYB-2 & 7.67 & 5.70 & 12.03 & 4.75 & 10.07 & 11.17 & 13.25 & 44.15 & 56.07 \\
\hline V3 & 2018/BOGHYB-3 & 8.33 & 5.21 & 13.60 & 3.86 & 10.63 & 11.93 & 15.40 & 48.00 & 60.96 \\
\hline V4 & 2018/BOGHYB-4 & 9.00 & 5.63 & 12.97 & 5.17 & 9.30 & 9.11 & 13.43 & 45.20 & 57.40 \\
\hline V5 & 2018/BOGHYB-5 & 12.66 & 5.10 & 12.68 & 6.69 & 10.37 & 12.15 & 10.30 & 44.37 & 56.35 \\
\hline V6 & 2018/BOGHYB-6 & 8.00 & 5.57 & 10.70 & 4.49 & 9.86 & 13.57 & 13.78 & 44.94 & 57.07 \\
\hline V7 & 2016/BOGVAR-1 & 8.15 & 4.96 & 12.23 & 5.89 & 10.50 & 17.00 & 9.87 & 39.01 & 49.55 \\
\hline V8 & 2016/BOGVAR-2 & 9.33 & 5.62 & 12.67 & 5.51 & 15.47 & 13.47 & 12.13 & 46.46 & 59.00 \\
\hline V9 & 2016/BOGVAR-3 & 9.10 & 6.47 & 11.60 & 6.25 & 12.20 & 16.80 & 14.37 & 43.38 & 55.09 \\
\hline V11 & 2016/BOGVAR-5 & 9.81 & 4.91 & 11.30 & 4.89 & 12.50 & 16.33 & 14.56 & 48.64 & 61.77 \\
\hline V12 & 2016/BOGVAR-6 & 11.30 & 5.94 & 9.43 & 3.98 & 14.47 & 15.17 & 11.15 & 46.17 & 58.64 \\
\hline V13 & 2016/BOGVAR-7 & 8.00 & 5.30 & 11.90 & 5.33 & 16.13 & 10.80 & 13.33 & 46.60 & 59.18 \\
\hline V14 & 2016/BOGVAR-8 & 9.67 & 6.06 & 12.21 & 6.07 & 16.70 & 15.67 & 13.69 & 39.27 & 49.87 \\
\hline V15 & 2016/BOGVAR-9 & 10.50 & 5.40 & 9.17 & 4.62 & 10.50 & 16.93 & 14.17 & 40.81 & 51.83 \\
\hline V16 & 2018/BOGVAR-1 & 9.35 & 6.15 & 8.96 & 4.37 & 16.33 & 13.40 & 10.07 & 41.08 & 52.17 \\
\hline V17 & 2018/BOGVAR-2 & 9.64 & 5.64 & 11.90 & 5.68 & 8.67 & 10.87 & 13.50 & 43.12 & 54.76 \\
\hline V18 & 2018/BOGVAR-3 & 8.05 & 6.33 & 12.07 & 4.13 & 7.78 & 17.53 & 13.83 & 42.56 & 54.05 \\
\hline V19 & 2018/BOGVAR-4 & 10.67 & 5.10 & 12.83 & 5.08 & 8.35 & 12.46 & 11.76 & 45.43 & 57.70 \\
\hline V20 & 2018/BOGVAR-5 & 8.76 & 5.36 & 12.20 & 6.44 & 9.40 & 13.10 & 11.00 & 48.77 & 61.93 \\
\hline V21 & 2018/BOGVAR-6 & 8.25 & 5.70 & 10.50 & 5.53 & 14.27 & 17.77 & 14.70 & 46.20 & 58.67 \\
\hline V22 & 2018/BOGVAR-7 & 11.00 & 5.49 & 11.63 & 4.54 & 11.00 & 10.33 & 12.60 & 48.33 & 61.38 \\
\hline V23 & KRISHNA & 9.40 & 5.67 & 12.50 & 4.80 & 14.60 & 10.60 & 14.17 & 42.25 & 53.66 \\
\hline V24 & 999 & 9.00 & 5.40 & 13.37 & 6.30 & 10.93 & 15.73 & 12.23 & 38.76 & 49.22 \\
\hline V25 & DEV & 9.50 & 5.05 & 11.20 & 5.90 & 13.23 & 15.63 & 9.03 & 40.27 & 51.14 \\
\hline V26 & SHIVA -60 & 9.96 & 4.55 & 10.27 & 4.24 & 14.30 & 17.50 & 9.56 & 39.01 & 49.55 \\
\hline F test & & $S$ & $S$ & $S$ & S & $\mathrm{S}$ & $\mathrm{S}$ & S & $S$ & $\mathrm{~S}$ \\
\hline$\overline{C D} @ 5 \%$ & & 0.93 & 0.53 & 1.15 & 0.50 & 1.25 & 1.39 & 1.20 & 1.96 & 2.49 \\
\hline Sed & & 0.46 & 0.26 & 0.57 & 0.25 & 0.62 & 0.69 & 0.60 & 0.98 & 1.24 \\
\hline
\end{tabular}

variety (13.77) followed byBOGHYB-3 (13.60). The results revealed that the growth parameters of bottle gourd significantly differed during the growth period. No. of primary branches varied from 3.86 to 6.69. Minimum no. of primary branches was recorded in case of varieties 2018/BOGHYB-3(V3), and the Maximum no. of petioles was recorded 6.69 in 2018/BOGHYB-5 variety. Petiole length varied from 7.78 to $16.70 \mathrm{~cm}$. Minimum petiole length was recorded in case of varieties 2018/BOGVAR-3, and the maximum Petiole length of $16.70 \mathrm{~cm}$ was recorded in 2016/BOGVAR-8, followed by2018/ BOGVAR-1 variety with $16.33 \mathrm{~cm}$ petiole length. At the initial stage of plant growth, there was a minor deviation in leaf length, but during the growth period, the leaf length varied from 9.11 to $17.77 \mathrm{~cm}$. The minimum of $9.11 \mathrm{~cm}$ and maximum leaf length of $17.77 \mathrm{~cm}$ was recorded in the case of varieties
2018/BOGHYB-4 and 2018/BOGVAR-6 followed by 2018/ BOGVAR-3 variety with $17.53 \mathrm{~cm}$.

Significantly maximum leaf width was recorded $15.40 \mathrm{~cm}$ in the variety 2018/BOGHYB-3 followed by $14.37 \mathrm{~cm}$ in the variety 2016/BOGVAR-3, and the Minimum leaf width of $8.53 \mathrm{~cm}$ was recorded in the case of varieties 2018/BOGHYB-1. Days to first female anthesis varied from 38.76 to 48.77 days. The maximum days (48.77) required to the first female flower anthesis was recorded in the case of variety 2018/BOGVAR-5followed by 48.67 in the variety 2016/BOGVAR-5 and the minimum days. Recorded to first female anthesis was 38.76 in the variety 2018/BOGHYB-1. Significantly maximum days to $1^{\text {st }}$ harvest of 61.93 was recorded in 2018/ BOGVAR-5 and the minimum of 49.22 in the variety 999, and at par to the variety SHIVA -60 with 49.55 . 


\section{CONCLUSION}

Analysis of variance revealed that there were significant differences among the varieties studied for all the characters. From the present investigation, it is concluded that among all the varieties 2016/ BOGVAR-1 variety has shown minimum days to first harvest and has given at par performance in all the parameters. So varieties 2016/BOGVAR1 2018/ BOGVAR-4, 2018/BOGHYB-2 can be recommended to eastern U.P. growers by few more conjunctive trials at different locations.

\section{REFERENCES}

Dubey, R.K. and Ram, H.H. 2008. Graphical analysis and numerical approach for a diallel analysis of yield components in bottle gourd [Lagenaria siceraria (Mol.) Standl.]. Cucurbit Genet. Cooperative, 29: 94-104.

Dubey, S.K. and Maurya, I.B. 2007. Combining ability for characters related to yield and earliness in bottle gourd [Lagenaria siceraria (Mol.) Standl.]. Indian J. Agric. Res., -IJAS., 41(1): 59-62.

Harika, M., Gasti, V.D., Shantappa, T., Mulge, R., Shirol, A.M., Mastiholi, A.B. and Kulkarni, M.S. 2012. Evaluation of bottle gourd genotypes (Lagenaria siceraria (Mol.) Standl.) for various horticultural characters. Karnataka J. Agric. Sci-IJAS., 25(2): 241-244.

Iapichino, G., Gentile, A. and Continella, G. 2009. Response of bottle gourd ecotypes [Lagenaria siceraria (Mol.) Standl] growing in Sicily. Italus. Hortus., 2(11): 720-723.

Jamal Uddin, A.F.M., Tahidul, M.I., Chowdhury, M.S.N., Shiam, I.H. and Mehraj, H. 2014. Evaluation of bottle gourd (Lagenaria siceraria) to growth and yield. International Journal of Biosciences - IJB., 5(12): 7-11.

Kanwar, M.S., Karia, B.N. and Kumar, S. 2003. Evaluation of cucumber genotype for yield and quantitative traits. Himanchal J. Agric. Res., 29(1/2): 43-47.

Kumar, R., Singh, D.K., Ram, H.H. and Kumar, R. 1999. Manifestation of bottle gourd [Lagenaria siceraria)Molina]. Annual Agric. Res., 20(2): 177-179.

Mangal, J.L., Dixit, J., Pandita, M.L. and Singh, A.S. 1981. Genetic variability studies in bitter gourd (Momordica charantia L.). Indian J. Hort., 38: 94-99.
Marie, I.A. and Mohammed, H.G. 2010. Effect of foliar application of potassium and IAA on growth and yield of two cultivars of squash (Cucurbita pepo L.). Journal of Tikrit University for Agricultural Sciences, 10(2): 229 - 242.

Mohanty, B.K. 2002. Studies on variability and selection parameters in pumpkin (Cucurbita moschata Duch ex. Poir). South Indian J. Hort., 48: 111-113.

Munshi, R. and Acharyya, P. 2005. Varietal evaluation in bottle gourd genotypes. Indian Agric., 49(3\&4): 213-221.

Pandey, R. and Singh, D.K. 2007. Seasonal effect on fruit yield and study of genetic variability on indigenous germplasm lines of sponge gourd (Luffa cylindrica Roem.). Ann. Agric. Res. New Series, 28(2): 184-191.

Pandit, M.K., Mahato, B. and Sarkar, A. 2009. Genetic variability, heritability and genetic advance for some fruit character and yield in bottle gourd [Lagenaria siceraria (Mol.) Standl.]. Acta Horticulturae, 809: 221-225.

Prasad, L., Gautam, N.C. and Singh, S.P. 1988. Studies on genetic variability and character association in watermelon [Citrulus lanatus (Thunb.) Mansf.]. Veg. Sci., 15(1): 86-94.

Ram, D., Singh, R.S., Pandey, S. and Rai, M. 2005. Study of polygenic traits in off season bottle gourd (Lagenaria siceraria (Mol) Stand L.). Veg. Sci., 32(2): 189-191.

Ram, H.H., Singh, T.R., Tripathi, P.C. and Rai, R.N. 1996. Indigenous germplasm resources in Curcurbits. Rajasthan Hort., 3(1): 70-75.

Ramchandran, C., Gopalakrishnan, P.K. and Peter, K.V. 1981. Genetic divergence in bitter gourd. Veg. Sci., 8(2): 100-104.

Singh, K.P., Choudhary, D.N., Singh, V.K. and Mandal, G. 1997. Combining ability analysis in bottlegourd [Lagenaria siceraria (Molina) Standl.]. J. Res., 8(1): 39-43.

Singh, S.P., Manrye, I.V. and Singh, N.K. 1996. Occurrence of Andromonocious from in bottle gourd [Lagenaria siceraria (Molina) Standil]. Exhibiting monogenetic recessive inheritance. J. Curr. Sci., 70: 458-459.

Solanki, S.S. and Seth, J.N. 1980. Studies on genetic variability in cucumber (Cucumis sativus L). Prog. Hort., 12(1): 43-49.

Vijay, O.P. 1987. Genetic variability in muskmelon (Cucumis melo L.). Indian J. Hort., 44(3-4): 233-238.

Wani, K.P., Ahmed, N. and Hussain, K. 2008. Gene action studies in bottle gourd Lagenaria siceraria (Mol.) Standl.]. Indian J. Agric. Sci., 78(3): 258-260. 